\title{
Mine rehabilitation in the Latrobe Valley, the start of a long journey: the Commissioner's role
}

\author{
R Mackay Latrobe Valley Mine Rehabilitation Commissioner, Australia \\ R Hastie Office of the Latrobe Valley Mine Rehabilitation Commissioner, Australia \\ H Lilley Office of the Latrobe Valley Mine Rehabilitation Commissioner, Australia \\ M Mathew Office of the Latrobe Valley Mine Rehabilitation Commissioner, Australia
}

\begin{abstract}
The Latrobe Valley in Victoria, Australia is rich in shallow and thick brown coal (lignite) seams and has been mined for electrical power generation for over 90 years. This sustained extraction has resulted in three very large open-cut mines-Hazelwood, Loy Yang, and Yallourn-that are within relatively close proximity to one another and major regional towns, and require continuous monitoring and management for stability and fire control. With changes in the electricity market, lignite mining for power generation is coming to an end and large-scale mine rehabilitation planning is underway to achieve safe, stable, and sustainable landforms as set by the Victorian government. All three mine operators are proposing pit lakes to meet these requirements. They are all at very different stages in their rehabilitation planning process: Hazelwood closed in 2017, while Yallourn and Loy Yang currently have 2032 and 2048, respectively, as their projected end of mining dates. Before pit lakes can be agreed, substantial efforts are needed to prove that they are feasible and justified. As part of the Victorian government's response to the need for a well-managed rehabilitation plan for the whole of the Latrobe Valley, the role of Commissioner for Latrobe Valley Mine Rehabilitation (Commissioner) was created in June 2017 by statute. The Commissioner's objectives are to oversee the planning for rehabilitation and to build community confidence in the planning processes and the future rehabilitation strategy. This paper describes the background to mine rehabilitation in the Latrobe Valley, the establishment, functions and powers of the Commissioner, and the observations around monitoring and evaluation and community involvement from the first 18 months of implementing the role.
\end{abstract}

Keywords: Latrobe Valley, commissioner, community engagement, monitoring and evaluation, lignite, brown coal

\section{Introduction}

The Latrobe Valley in Victoria, Australia, holds some of the world's largest deposits of brown coal (lignite). These deposits have been exploited since 1874 (Context Pty Ltd 2010), with the first state-run coal mine opening in 1916. The State Electricity Commission of Victoria (SECV) was the primary architect of the major expansion of brown coal mining for electricity generation with the initial coal extraction sited at the Yallourn mine. Hazelwood (formerly known as Morwell open cut) mine was commissioned to service the coal requirements of Hazelwood power station, which was constructed between 1964 and 1971. Finally, Loy Yang mine was commissioned to service a substantial expansion of power generation with the introduction of the Loy Yang A and Loy Yang B power stations, completed in 1988 and 1996, respectively. At the height of power generation, the Latrobe Valley was generating ninety percent of Victoria's electrical power needs. The power stations and mines were privatised in 1995.

The Latrobe Valley currently supports two operational (Yallourn and Loy Yang) and one recently closed (Hazelwood) brown coal mines, supplying most of Victoria's energy demands. While the Latrobe Valley coal reserves are sufficient to supply Victoria's energy demands for several hundred years, Australia's electricity market is moving toward a greater proportion of renewables and storage. There is a clear drive to reduce 
$\mathrm{CO}_{2}$ emissions, and with the move away from fossil fuels, lignite mining for power generation in the Latrobe Valley is coming to an end. Hazelwood ceased production in 2017, Yallourn plans to close in 2032, and Loy Yang 2048.

Despite the Latrobe Valley's long history of mining, there was little government or operator consideration of rehabilitation of the mine voids prior to this century. The SECV did not begin considering rehabilitation of the mines until the late 1970s-early 1980s, and its rehabilitation planning was considered insufficient. According to the Auditor General of Victoria (1993), "the SECV had not demonstrated that there was a structured and coordinated approach to achieving its environmental objective in the areas of land rehabilitation of open cuts".

Following the disestablishment of the SECV and privatisation of the mines in the mid-1990s, the new mine operators provided the government with an AUD 15 million rehabilitation bond and a rehabilitation plan. In 2004, the bond for Yallourn mine was reduced to AUD 11.46 million. However, these rehabilitation plans (and bonds) were found to be insufficient to ensure a safe, stable, and sustainable landform would be returned to the community if the mine operators failed to meet their obligations (Hazelwood Mine Fire Inquiry [HMFI] 2016a).

\subsection{Recent events}

The Latrobe Valley brown coal mines have not operated without incident; with fires, flooding and batter failures occurring infrequently but consistently throughout their operational lives. A recent series of critical failures in relatively quick succession prompted greater government scrutiny into the Latrobe Valley mining operations.

In 2007, a large section of Yallourn's northern batter collapsed due to a mechanism known as block sliding: as mining progressed close to the Latrobe River, groundwater pressures sustained by river inflows in the coal joints close to the river drove a coal block on the weaker interseam sediments into the mine. Approximately $6 \mathrm{MCM}$ of material over a length of $500 \mathrm{~m}$, with a face height of $80 \mathrm{~m}$, were displaced by the slide. This resulted in the Latrobe River entering the mine, damaging critical mine infrastructure, and disrupting mining operations (Yallourn Mine Batter Failure Inquiry 2008).

In February 2011, Hazelwood's northern batters underwent a small but significant movement following a period of heavy rainfall causing high flows in an unlined stormwater drain lying relatively close to the batter. A series of cracks appeared in the Princes Freeway (a significant regional arterial road) as well as a major road in the adjacent township of Morwell. A large section of the freeway was closed and was not reopened until September 2011 after a period of investigation and remedial action (HMFI 2016a).

In 2012, at Yallourn mine, a section of the Morwell River Diversion collapsed, partially flooding an active field and fully flooding a worked-out field. The diversion was not fully restored until January 2014 (HMFI 2016a).

\subsection{Hazelwood mine fire}

In February 2014, during one of the hottest and driest summers ever recorded in Victoria, embers from a nearby bushfire landed in Hazelwood mine and ignited a mine fire that burned for 45 days. The fire had a significant impact on the Latrobe Valley community, particularly in the town of Morwell. Vulnerable community members were belatedly evacuated due to ash and smoke, and the enduring health impacts on the town's population are still yet to be fully understood, with health and social impact studies continuing through the Hazelwood Health Study (http://hazelwoodhealthstudy.org.au/).

In March 2014, the Victorian Government established an independent board of inquiry to examine the cause and responses to the Hazelwood mine fire, including the adequacy and effectiveness of regulations relating to mine fires. The inquiry reported on 29 August 2014 (HMFI 2014), however, the inquiry was reopened in May 2015 following a change in government. The aim of the 2015-16 inquiry was not to re-examine the findings of the 2014 inquiry - the findings and recommendations from the 2014 inquiry were accepted-but to examine issues not captured by the original terms of reference. 
The 2015-16 mine fire inquiry terms of reference focused mainly on health impacts and rehabilitation. The establishment of the Commissioner came out of the recommendations of the 2015-16 inquiry.

\subsection{Key findings of the Hazelwood mine fire inquiry}

The final report of the reopened inquiry was released on 14 April 2016. Across its four reports, the reopened inquiry made recommendations to improve the health of the Latrobe Valley community, strengthen the state's mining regulation, and promote effective mine rehabilitation planning. The Victorian government's response to both the 2014 and 2015-16 inquiries was to accept all recommendations. In June 2016, the government published its implementation plan, containing 245 action items including the establishment of the Latrobe Valley Mine Rehabilitation Commissioner (LVMRC) (HMFI 2016b).

This paper provides an overview of the establishment and operation of the LVMRC role and observations from the first 18 months of operation. It considers the interaction between the Commissioner and the Latrobe Valley Regional Rehabilitation Strategy (LVRRS), and the role that each play in planning for rehabilitation of the three Latrobe Valley brown coal mines. It also briefly examines the key role that stakeholder and community engagement activities have played in developing public confidence in the rehabilitation planning.

\section{$2 \quad$ Latrobe Valley mines and mines risks}

To appreciate properly the task that the LVMRC has been set, it is worthwhile briefly considering the features of the three brown coal mines and the mining risks relevant to rehabilitation arising from the regional geological and hydrogeological setting.

\subsection{Overview of the three Latrobe Valley brown coal mines}

The Latrobe Valley brown coal mines (Figure 1) are each at different stages of operation and rehabilitation planning. Basic data relating to their operations are presented in Table 1 . While there are some commonalities between the three, there are also significant differences that impact on regional rehabilitation planning.

\subsubsection{Hazelwood}

Hazelwood mine ceased operations in March 2017 with the closure of Hazelwood Power Station. The mine owner, ENGIE, is currently working through the studies and actions necessary to develop a final rehabilitation and closure plan. ENGIE's preferred rehabilitation landform concept is a full pit lake and surrounding land is rehabilitated for an open space use such as agricultural or recreational purposes, with alternative future uses permissible depending on predicted ground stability. Hazelwood's final rehabilitation and closure plan is anticipated to be submitted to the Victorian government for approval by the start of 2021, which is also when ENGIE proposes to commence filling the pit with water. ENGIE is currently undertaking 'no regrets' earthworks that they anticipate are applicable to the final approved rehabilitation landform.

\subsubsection{Yallourn}

Yallourn mine, owned by EnergyAustralia, is the oldest of the three open cut coal mines and will have produced $1.3 \mathrm{Bt}$ by its planned closure in 2032. It is also the shallowest with a mining depth less than $90 \mathrm{~m}$ and has the highest overburden to coal ratio (more than 1:3). Currently, the mine produces $18 \mathrm{Mt}$ of brown coal annually via dozer push to supply Yallourn Power Station, also owned by EnergyAustralia and scheduled for closure in 2032. Yallourn's current rehabilitation plan is a full pit lake interconnected with the Morwell River, which is currently diverted through the centre of the mine, via an aqueduct on an earth embankment. Yallourn is currently undertaking progressive rehabilitation in terms of placing overburden as surcharge and batter shaping. Extensive interim rehabilitation has also been undertaken, comprising coal cover and revegetation of selected areas that may not contribute to the final landform. 


\subsubsection{Loy Yang}

AGL's Loy Yang mine has the highest production rate of the three mines with an annual coal output of approximately $28 \mathrm{Mt}$. It is also the deepest and coal is mined via bucket wheel excavators to a maximum depth of $220 \mathrm{~m}$. Loy Yang's mining operations are presently scheduled to cease in 2048, in line with the closure of the two power stations receiving its coal.

With respect to rehabilitation, AGL is also proposing that Loy Yang become a pit lake, with the final height (i.e. a full or partial pit lake) yet to be determined. AGL are undertaking progressive rehabilitation works with reshaping of the overburden dump and selected batters. Field trials on batter covers and artificial top soils are underway.

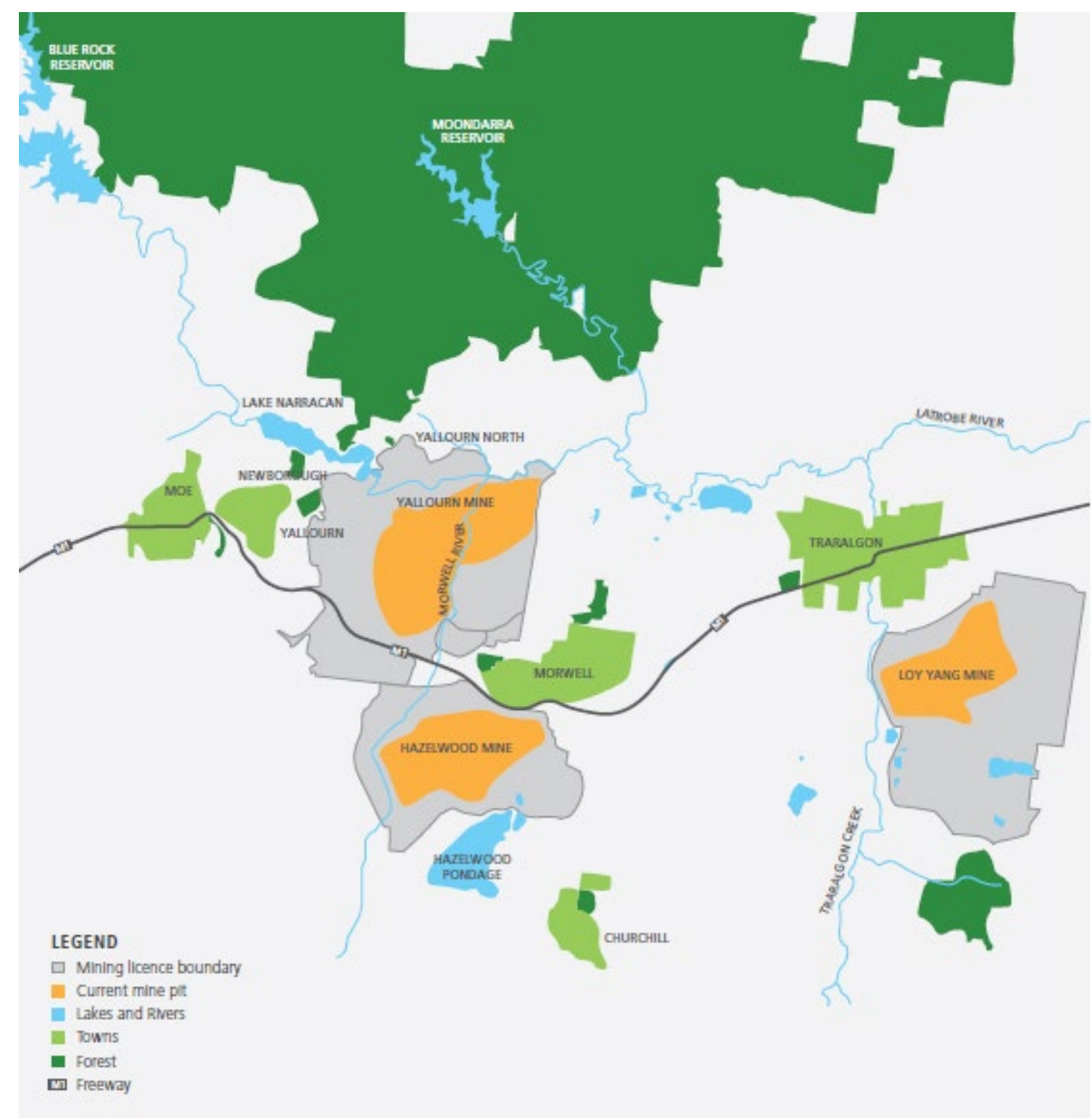

Figure 1 The location and extent of the Latrobe Valley brown coal mines (Courtesy of Reactivate Latrobe Valley) 
Table 1 Overview of Latrobe Valley brown coal mines

\begin{tabular}{|c|c|c|c|}
\hline Mine (current owner) & $\begin{array}{l}\text { Hazelwood } \\
\text { (ENGIE) }\end{array}$ & Yallourn (EnergyAustralia) & Loy Yang (AGL) \\
\hline \multirow[t]{2}{*}{ Commenced operation } & \multirow[t]{2}{*}{1964} & 1974 & \\
\hline & & $\begin{array}{l}\text { Mining at Yallourn North Open Cut } \\
\text { commenced in the 1920s }\end{array}$ & 1985 \\
\hline Mining lease/s & MIN5004 & MIIN5003, MIN5216, MIN5304 & MIN5189 \\
\hline Mining lease area & $3,320 \mathrm{Ha}$ & $5,595 \mathrm{Ha}$ & $4,560 \mathrm{Ha}$ \\
\hline Disturbed land area & $2,500 \mathrm{Ha}$ & $2,800 \mathrm{Ha}$ & $1,900 \mathrm{Ha}$ \\
\hline Mine area (final) & $1,176 \mathrm{Ha}$ & $\begin{array}{l}2,040 \mathrm{Ha} \\
(2,300 \mathrm{Ha})\end{array}$ & $\begin{array}{l}930 \mathrm{Ha} \\
(2,200 \mathrm{Ha})\end{array}$ \\
\hline Mine depth (approx.) & $\max 130 \mathrm{~m}$ & $\max 95 \mathrm{~m}$ & $\max 200 m$ \\
\hline $\begin{array}{l}\text { Groundwater extraction } \\
\text { licence per year }\end{array}$ & $22 \mathrm{GL}$ & $3 G L$ & $20 G L$ \\
\hline $\begin{array}{l}\text { Total coal produced to } \\
\text { date (approx.) }\end{array}$ & $\begin{array}{l}770 \text { million } \\
\text { tonnes }\end{array}$ & 1,100 million tonnes & $\begin{array}{l}800 \text { million } \\
\text { tonnes }\end{array}$ \\
\hline $\begin{array}{l}\text { Planned date for } \\
\text { cessation of mining }\end{array}$ & 2017 & 2032 & 2048 \\
\hline
\end{tabular}

\subsection{Mine risk management}

For the three mines, there are two primary areas of risk-fire and ground instability - that require continuous mitigation to achieve a safe and stable landform during mining. The Hazelwood Mine Fire Inquiry (HMFI) (2016a) found that effective rehabilitation will ideally enable passive management of these risks.

\subsubsection{Ground stability control and subsidence}

Several factors contribute to instability within the Latrobe Valley's brown coal mines, with two key geological properties being:

1. Shallow and thick coal seams up to $100 \mathrm{~m}$ thick, which, when interbedded between variable thickness clay/silt/sand interseams, create almost continuous coal thicknesses of up to $230 \mathrm{~m}$ (Gloe 1960).

2. The coal's low density of approximately 1.11 to 1.14 t per cubic metre (Higgins et al. 1980), which renders it susceptible to buoyancy and lateral hydraulic forces.

Two major water-induced failure mechanisms can occur: infiltration into relaxing joints can cause large coal block sliding events, and groundwater pressure within the deep, confined aquifers results in mine floor heave. Ground control management is essential for each of the mines and is focussed on both groundwater and surface water management. Heave is controlled by groundwater depressurisation of the major aquifers below the mine, while block sliding is controlled via groundwater depressurisation of the coal and coal joints using horizontal boreholes.

Owing to the confined aquifers' depressurisation, ground subsidence is a major feature across the Latrobe Valley. It occurs at a rate of $10-20 \mathrm{~mm}$ per year around the mines and has exceeded $2 \mathrm{~m}$ below Morwell to the north of Hazelwood. Regionally the subsidence bowl extends out for more than $20 \mathrm{~km}$ from the mines. While the areal extent has been large, subsidence has been largely uniform over the region leading to very few cases of significant infrastructure or property damage. 
Ideally, rehabilitation will permit groundwater depressurisation to cease allowing the aquifers to recover. Pit lakes provide for this outcome. Subsidence rebound is expected to occur as groundwater pressures rise (although the amount of rebound is not yet well understood).

\subsubsection{Fire prevention and response}

As evidenced by the Hazelwood mine fire in 2014, fire management is a critical issue. On top of bushfire risks, combustion risks from an operating plant are present in all operational areas with exposed coal. Latrobe Valley brown coal is also susceptible to spontaneous combustion when exposed to oxygen and naturally occurring fire holes have been observed. As a result, each mine maintains extensive fire emergency response programs and infrastructure, including large water mains around the perimeters of the mines and sprinklers on batters and the mine floor.

Interim and progressive rehabilitation is generally undertaken to reduce the extent of exposed coal, and thus, the fire risk. Significant areas of steep batter slopes that are planned to be submerged by the pit lake and are not easily covered remain exposed.

\section{Role of the Commissioner}

The role of the LVMRC was established in response to recommendation 14 of the 2015-16 HMFI. The Commissioner is an independent officer of the State of Victoria, appointed by the Governor in Council on the recommendation of the Minister for Resources (the Minister).

The Commissioner's role requires significant technical expertise as well as engagement experience and is based in the Latrobe Valley. The Commissioner is supported by a small staff providing technical advice, engagement capacity and business management.

\subsection{Objectives}

The Commissioner's appointment, objectives, functions and powers are governed by Part 7A of the Mineral Resources (Sustainable Development) Act 1990 (the Act) (Government of Victoria 1990). Under s84AE of the Act, the Commissioner's objectives are:

- To provide assurance to the Victorian community that public sector bodies and the Latrobe Valley licensees are planning for the rehabilitation of coal mine land, and implementing the regional rehabilitation strategy.

- To promote the participation of the community and stakeholders from the Latrobe Valley region in the development and implementation of the regional rehabilitation strategy.

- To promote the effective and consistent rehabilitation of coal mine land in accordance with the regional rehabilitation strategy.

\subsection{Functions}

The Commissioner's powers are defined by section 84AL of the Act, and include (but are not limited to):

- Developing and maintaining a framework for the monitoring and evaluation of rehabilitation planning activities.

- Carrying out strategic audits, if deemed necessary, of Latrobe Valley licensees and public sector bodies in relation to rehabilitation planning activities.

- Reviewing research plans in relation to the rehabilitation of coal mine land prepared by Latrobe valley licensees.

- Coordinating rehabilitation planning activities.

- Engaging with and conducting meetings between relevant groups and persons. 
- Providing information and education to the Victorian community about brown coal mine land rehabilitation and the rehabilitation strategy.

- Carrying out investigations on the referral of the Minister.

- Providing advice and recommendations to the Minister on matters related to the exercise of the commissioner's powers and functions.

The Act grants the Commissioner all powers necessary or convenient to perform these functions and they must be performed in regard to the objectives of the Commissioner, the regional rehabilitation strategy and the regulatory framework.

\subsection{Consistent aims}

To implement the objective 'to promote the effective and consistent rehabilitation of coal mine land...', the Commissioner's activities and approach to rehabilitation are founded on the three key principles of mine rehabilitation:

1. Safe.

2. Stable.

3. Sustainable.

As such, the first task was to build consensus with major stakeholders, including the three mine licensees and the LVRRS, on the meaning of these terms as a basis for rehabilitation planning. This was particularly pertinent for the LVRRS, to ensure that the study's project team had the same understanding of rehabilitation goals as the Commissioner and licensees. This also enables consistent messaging to community groups when discussing the aims and future outcomes of mine rehabilitation.

\subsubsection{Safe}

The final landform should present the lowest reasonably achievable risk to public health and safety and the environment, both within and beyond the mine boundaries. A range of possible hazards need to be addressed including fire, dust, contamination of air, soil and water, detrimental or uncontrolled water flows, or the development of weak or dangerous ground. Controls necessary to maintain safe conditions should be in place with appropriate actions, such as monitoring.

\subsubsection{Stable}

Future ground movements of the final landform should be minimised as far as reasonably practicable and those movements that will occur should be understood, predictable, and controllable. Controls necessary to maintain stability within and beyond the mine boundary should be in place with appropriate monitoring. The risks of rapid, adverse ground movements leading to damage to infrastructure, property, or the environment should be as low as reasonably achievable. Any risk to human life should be identified and addressed.

\subsubsection{Sustainable}

The final landform, including any water bodies, should be feasible from long-term stability, environmental, social, and economic perspectives, and capable of beneficial use. The ongoing management, monitoring, and maintenance of the landforms including any water bodies should be well defined and the appropriate financial and regulatory provisions for these activities in place.

\subsection{The Latrobe Valley Regional Rehabilitation Strategy}

A fourth area of consensus was required with respect to the LVRRS. The LVRRS was established in response to recommendations 13,14 , and 18 of the HMFI that potential regional impacts from rehabilitating the three brown coal mines were not well understood, including the potential regional impacts from filling, either 
partially or fully, the mine voids with water to create pit lakes. Led by the Victorian government's Department of Jobs, Precincts and Regions (DJPR) in collaboration with the Department of Environment, Land, Water and Planning (DELWP), the LVRRS commenced its program of works in 2017 and is due to deliver its findings by June 2020.

\subsubsection{Project scope}

The LVRRS's scope was defined by the Hazelwood Mine Fire Inquiry: Victorian Government Implementation Plan (HMFI 2016b), which states that DJPR and DELWP, in collaboration with the mine operators and the Latrobe Valley community, and with input from technical experts, are to investigate the feasibility of full pit lake and partial pit lake rehabilitation options for the Latrobe Valley coal mines, which were found by the HMFI to be "currently the most viable rehabilitation option" (HMFI 2016a). The LVRRS was tasked with (Government of Victoria 2018):

- Investigating and addressing knowledge gaps relating to potential regional impacts from mine rehabilitation, including geotechnical stability, hydrogeological risks and water availability.

- Working with the community and the operators of the Latrobe valley coal mines to understand the findings of these investigations.

- Developing a strategy to guide regional-level planning for mining operations, rehabilitation, mine closure and post closure, taking account of the interconnectivity between the three mine voids.

Further to the above, a Land Use Planning Study, which was not required by the implementation plan, was also included in the LVRRS's scope to ensure a holistic consideration of regional rehabilitation, and to ensure that community preferences for future land use are captured and considered.

\subsubsection{Developing consensus on 'strategy'}

Early in the LVRRS's development, the Commissioner set out to gain consensus on what a strategy should achieve, and the following was agreed upon with the LVRRS. This consensus, similar to defining safe, stable and sustainable, is important in framing the work of the LVRRS, gaining an understanding of how the LVRRS will complement and ideally provide certainty to the mine licensees, and providing a basis for the Commissioner's perspective with respect to output review and general advice:

- The strategy will define the goals to be achieved for the rehabilitation of the three mines. These goals will be high-level rather than prescriptive, but will provide clear direction to the mine licensees, the community, and government on:

- acceptable approaches to rehabilitation.

- expected outcomes from the rehabilitation in terms of the limits to be placed on any impacts arising from rehabilitation.

0 the opportunities for future beneficial use of the land and water bodies that may be developed through rehabilitation.

- coordination of rehabilitation and the oversight of the rehabilitation processes.

○ the approach to managing long term monitoring, maintenance and reporting of rehabilitation outcomes.

o the financial and organisational provisions required to support effective rehabilitation and management of any long-term liabilities arising from the rehabilitation.

This definition has also helped frame the involvement and expectations of the licensees in the LVRRS's development. 


\subsection{Monitoring and evaluation framework}

The Act (Government of Victoria 1990) requires the Commissioner to prepare a monitoring and evaluation framework for rehabilitation planning activities. The Commissioner published the Latrobe Valley Rehabilitation Monitoring Framework 2018-20 (the Framework) (Latrobe Valley Mine Rehabilitation Commissioner [LVMRC] 2018) in November 2018 and used its development as a further opportunity to gain consensus amongst key stakeholders on the Commissioner's role in their respective rehabilitation planning and implementation programs.

\subsubsection{Objectives}

The Commissioner designed the Framework with the following key objectives in mind:

- Encompass the broad range of actions that the Commissioner oversees for the four major stakeholder categories:

- Planning operations by each of the three Latrobe Valley brown coal mines.

- Regional rehabilitation planning work produced by the LVRRS.

- The mine operators' collective research program, the Integrated Mines Research Group.

- Public sector bodies, e.g. regulators (Earth Resources Regulation and the Environment Protection Authority) and planning and development departments (DELWP and DJPR).

- Embed the Commissioner's oversight into the existing operational arrangements for each of the above stakeholders including the reporting, meeting and dissemination pathways adopted by these organisations.

The second point, above, is considered essential to the Commissioner's role as this prevents delays and barriers to the Commissioner's involvement in rehabilitation activities and outputs as it avoids creating new processes and new reporting activities solely for the Commissioner's use.

\subsubsection{Approach to design}

While considerable value has been derived from maintaining an open dialogue through regular face-to-face meetings with stakeholders, the framework largely focuses on reviews of documentary evidence. This approach provides a cleaner pathway for providing commentary than through meeting notes and meeting minutes alone.

For the monitoring and evaluation of each groups' activities, the Commissioner adopted a log framework approach. The log framework format (Figure 2) defines a hierarchy of activities, outputs, and outcomes leading to the required goal (as shown by the arrows). It outlines the indicators and their means of verification to confirm that progress has been made. The log framework further highlights the risks and assumptions that are implicit in each step from activities to goal for the stakeholder. Verification is achieved via the assessment of output and outcome performance against the identified risks and assumptions. 


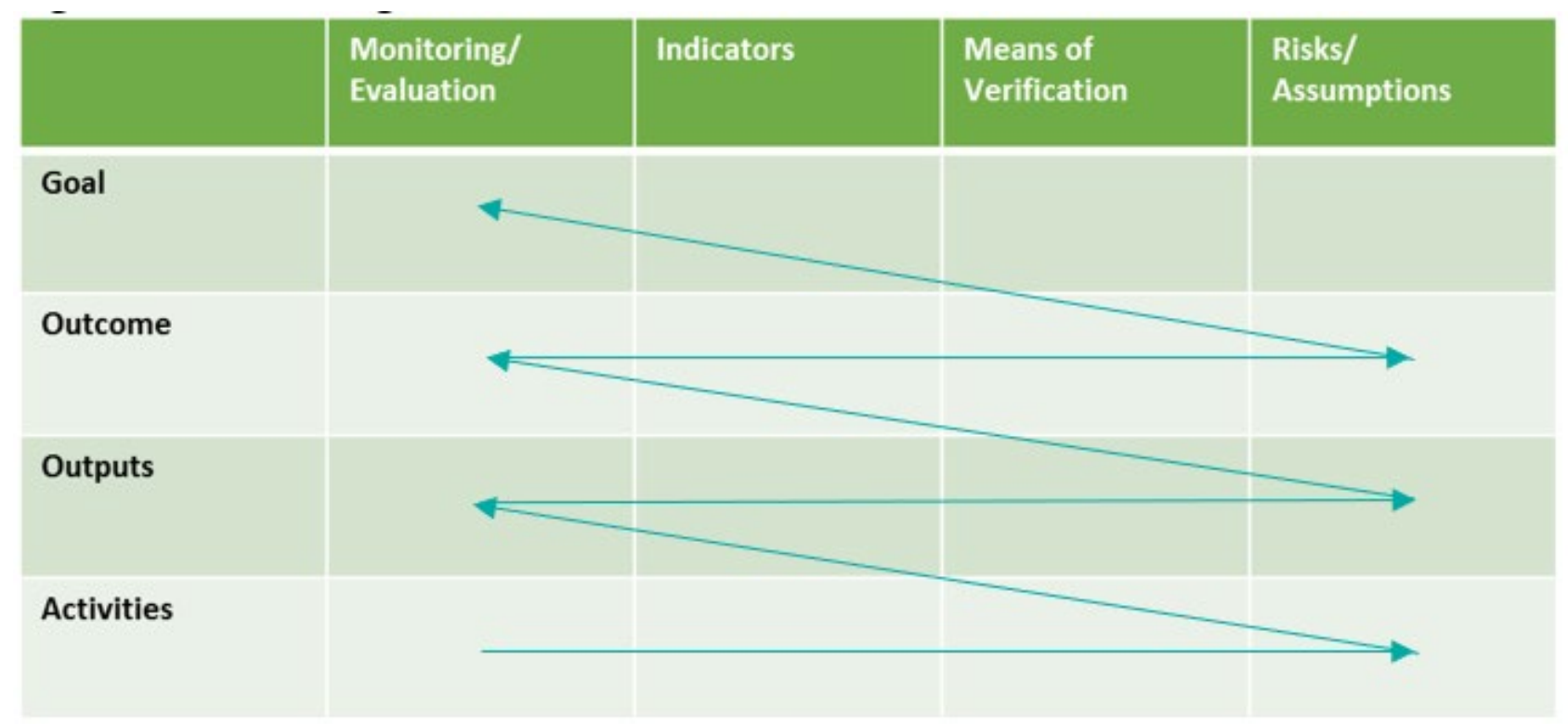

Figure 2 Monitoring and evaluation framework concept (LVMRC 2018)

Activities, outputs, outcomes, and the goal are described in high-level terms for two reasons: firstly, that specific stakeholder activities are subject to regular revision and redefinition, which, if adopted, would render the framework quickly out of date, and secondly, the high-level activities, outputs, and outcomes identified are the most critical in terms of demonstrating the progress and adequacy of the rehabilitation planning.

\subsection{Providing certainty to stakeholders}

Through working with stakeholders and community groups, one common theme continues to emerge: that government policy certainty and consistency is essential for successful mine rehabilitation. Particularly for the Latrobe Valley, certainty is required with respect to whether the government will approve-if the need is demonstrated -the volume of water required to create the preferred pit lake landforms at an appropriate rate and reliability (the provision mechanism), as it has the following impacts:

- Enables licensees to plan rehabilitation budgets, timelines, and most importantly, scope. For the two licensees that are still actively mining, this is particularly important as rehabilitation planning should be an inherent part of mine planning and operation, whereby rehabilitation can be streamlined through the integration of final landform design into mining plans and works.

- Enables whole of government decision making with respect to multiple policy areas, including land use planning, water entitlements, and infrastructure development in the Latrobe Valley.

- Enables consistent communication with non-technical stakeholders, such as community groups, providing confidence about the future of the Latrobe Valley.

Regional development groups also benefit from rehabilitation certainty as organisations such as Regional Development Victoria and the Latrobe Valley Authority focus on attracting industries and jobs that complement the future landforms of the area.

Further to the above, the Commissioner would prefer that policy arising from the LVRRS is enabling rather than prescriptive, meaning that the licensees are able to make technical and economic decisions related to mine rehabilitation, within the lens of 'safe, stable, and sustainable', without having a landform or approach prescribed by the government. This avoids transfer of ownership of the risks from the mine operators to the state. 


\subsection{Engagement}

Community engagement forms a substantial aspect of the Commissioner's work and is given equal importance to technical reviews and informing policy. It is critical to the Commissioner that rehabilitation planning, progress and policies are understood and supported by the wider community.

At this stage, community engagement activities have primarily focussed on two areas: educating the community and listening to the community's views.

\subsubsection{Community trust}

The Latrobe Valley community is perceived as distrustful of private enterprise and government agencies, partially due to the SECV privatisation in the 1990s, which triggered a downturn in the region due to the high number of redundancies, and partially due to the emergency response relating to public health from the Hazelwood mine fire among other more minor instances of unmet expectations. Through discussion, community members have expressed significant reservations about the final landform's future value to the region as they are unsure a pit lake would be a positive outcome.

Rehabilitated landforms, such as pit lakes that could restrict future mining options, are regarded as a poor outcome for those community members who have a strong preference to see a continuation of mining. The suggested use of water to fill a mine void is perceived as a waste of a valuable resource for those community members who are affected by drought. The possible impacts on the ecosystems downstream of the mines from the reduction of water in the rivers during lake filling and the possible water quality impacts thereafter are significant issues for those community members who are concerned for the environment. Additionally, future land ownership, public access to the land and how lakes will result in future beneficial uses are areas of strong interest for those community members who are concerned for future employment opportunities. This mix of concerns has common foundations: a need to see positive outcomes for the community, a lack of adequate and reliable information on the approaches being employed by government and the mine operators to decide rehabilitation preferences, and a lack of knowledge of the underpinning science both for and against different landform options.

Accordingly, building community awareness of the reasons for investigating lake options for the final landform and the work being undertaken by the key stakeholder groups has been at the forefront of Commissioner's community engagement activities. Importantly, it has been essential to relate to the concerns expressed and to explore through dialogue those parts of the rehabilitation planning processes that directly address the community concerns. Most importantly, where discussions have highlighted issues that need consideration by key stakeholders, those issues are raised with the stakeholders by the Commissioner on behalf of the community and the responses fed back to the community. The independence of the Commissioner is essential in this regard. Connecting with the community in this way has been important for building trust.

To further build trust, the Commissioner has focussed on open, honest, and frequent communication through education via various fora (described in the following subsection). While trust is difficult to measure, the Commissioner's repeated engagement with local community groups, such as being asked to present at multiple meetings for the one organisation and the high attendance rate at LVMRC fora, are indicators that the Commissioner presents a valued perspective on mine rehabilitation.

A future critical aspect to progressing trust between the community and government will be how the findings of the LVRRS are made public and that the reasoning and constraints on rehabilitation strategy are fully and transparently explained.

\subsubsection{Knowledge development}

In deciding rehabilitation outcomes, there is a clear tension between the desirability of a particular land form/land use and the technical constraints that govern both the implementation cost and the practicality of achieving the desired result. For many community members the constraints appear as barriers and not as 
guides to decision-making, which leads to frustration with rehabilitation planning processes. Building a common understanding of the technical constraints to rehabilitation can reduce this tension but is only achievable by sharing knowledge and exploring different points of view. A range of different platforms are being used to achieve this goal:

- Biannual fora, each with a different focus, to share knowledge.

- Meeting with local community, government and other interested groups to provide an overview of rehabilitation planning to date and answer any questions they may have. Entering open conversations provides a powerful means to reach consensus and acceptance of ideas.

- Attending events hosted by other stakeholders, to understand community concerns.

- Providing online material such as fact sheets.

- Hosting educational events, e.g. through Science Week, in collaboration with educational partners.

Other engagement activities have focused on regularly disseminating information so that the community can continue to be informed and build their knowledge around the wider context for rehabilitation. Facebook provides an accessible platform for exploring a wide range of news and developments related to rehabilitation.

\section{$4 \quad$ Future milestones}

Between now and the end of 2020 , several rehabilitation planning milestones will be met. This is an exciting period where the rehabilitation strategy for the Latrobe Valley will begin to take shape and key decisions will be made.

\subsection{Hazelwood rehabilitation and closure plan}

The majority of the studies needed to complete the development of the rehabilitation and closure plan for Hazelwood mine will be complete before the end of 2020 and the plan will be submitted to the State Government for evaluation.

\subsection{Strategy publication}

The LVRRS will be finalised and released to the public in mid-2020. At the moment, the LVRRS is in a critical juncture where the findings of the various working groups and early recommendations will begin to be put to the community and licensees.

\subsection{Statutory Authority implementation}

Once the LVRRS is published, government attention will turn to implementation. The task of implementing the LVRRS, monitoring rehabilitation activities and overseeing further technical studies will fall to a new entity - the Mine Land Rehabilitation Authority (the Authority).

Establishing the Authority was a recommendation of the HMFI (2016a, 2016b), after the inquiry found that Victoria's legal requirements for mine rehabilitation and closure were unclear.

\section{Conclusion}

The 2015-16 HMFI, and the government's implementation of its recommendations, marked a fundamental shift in Victoria's approach to mine rehabilitation. Establishing the role of the Commissioner recognised the value of having a completely independent expert to oversee rehabilitation planning and provide advice directly to the Minister. The mining environment in the Latrobe Valley is complex due to the proximity of the mines to each other, to infrastructure and large community centres. This, and the nature of the ground conditions, leads to complexity for planning, which is compounded further by the many stakeholders with 
overlapping roles and responsibilities. Facilitating communication between stakeholders has proven to be valuable for progressing rehabilitation planning in this environment. Moreover, by choosing to monitor and evaluate planning through use of the many existing reporting pathways adopted among the different stakeholders, the burden on the stakeholders is substantially lessened, which helps create a constructive dialogue while still providing all the evidence required to ensure that planning is coherent among the many stakeholders. The use of existing reporting pathways also allows more immediate evaluation of plans.

Having an independent Commissioner responsible for educating and informing the community about rehabilitation planning recognises the importance of the local community in successful mine rehabilitation. It also recognises that government has a critical role to play in providing assurance to the community that rehabilitation is being properly conducted. By adopting a consensus building approach to knowledge development the community can acquire the knowledge needed to evaluate the rehabilitation plans as well as share concerns and aspirations for the final landform and land uses that will be delivered. Using a wide range of platforms for meaningful conversations between the community, stakeholders and the Commissioner has gained general acceptance and is achieving good outcomes.

Delivering certainty in rehabilitation planning outcomes to support decision making is a key goal for the Latrobe Valley's future rehabilitation strategy.

\section{Acknowledgement}

The Commissioner would like to acknowledge the LVRRS team, each of the mine licensees (ENGIE, AGL and Energy Australia), the Integrated Mines Research Group and the Latrobe Valley Community in general for their role in rehabilitation planning and progress.

\section{References}

Auditor General of Victoria 1993, Special Report No. 24 Open Cut Production in the Latrobe Valley, GP V 1992/94 no. 27, viewed 29 March 2019, http://www.parliament.vic.gov.au/papers/govpub/VPARL1992-94No27.pdf

Context Pty Ltd 2010, Latrobe City Heritage Study Volume 1: Thematic Environmental History, viewed 4 April 2019, http://www.latrobe.vic.gov.au/files/dac98f81-599f-4189-aefc-a0d7011b4a8d/Latrobe_City_Heritage_Study.pdf

Latrobe Valley Mine Rehabilitation Commissioner 2018, Latrobe Valley Monitoring and Evaluation Framework 2018 , viewed 11 April 2019, https://www.lvmrc.vic.gov.au/monitoring-framework/

Gloe, CS 1960, The Geology of Latrobe Valley Coal Fields, Australian Institute of Mining and Metallurgy, Carlton.

Government of Victoria 1990, Mineral Resources (Sustainable Development) Act 1990, Commonwealth of Australia, viewed 13 April 2019, http://www6.austlii.edu.au/au/legis/vic/consol_act/mrda1990432.pdf

Government of Victoria 2018, Latrobe Valley Regional Rehabilitation Strategy Program Summary, Department of Economic Development, Jobs, Transport and Resources, viewed 02 April 2019, https://earthresources.vic.gov.au/_data/assets/ pdf_file/0004/464773/Latrobe-Valley-Regional-Rehabilitation-strategy-program-summary.pdf

Hazelwood Mine Fire Inquiry 2014, Hazelwood Mine Fire Inquiry Report, Parliament of Victoria, viewed 11 April 2019 , http://report.hazelwoodinquiry.vic.gov.au/

Hazelwood Mine Fire Inquiry 2016a, Hazelwood Mine Fire Inquiry Report 2015/2016 Volume IV-Mine Rehabilitation, Parliament of Victoria, viewed 11 April 2019, http://hazelwoodinquiry.vic.gov.au/wp-content/uploads/2015/09/Hazelwood-Mine-FireInquiry-Report-2015-2016-Volume-IV---Mine-Rehabilitation-web.pdf

Hazelwood Mine Fire Inquiry 2016b, Hazelwood Mine Fire Inquiry: Victorian Government Implementation Plan, Parliament of Victoria, viewed 2 April 2019, https://www.Ivmrc.vic.gov.au/wp-content/uploads/2017/12/Hazelwood-Inquiry-ImplementationPlan.pdf

Higgins, RS, Kiss, LT, Allardice, DJ, George, AM \& King, TNW 1980, Properties of brown coal from the Latrobe Valley-a basis for the evaluation of quality, State Electricity Commission of Victoria Research and Development Department Report, no. SC/80/17.

Yallourn Mine Batter Failure Inquiry 2008, Mining Warden Yallourn Mine Batter Failure Inquiry, viewed 1 April 2019, https://www.parliament.vic.gov.au/papers/govpub/VPARL2006-10No156.pdf 
